\title{
A BIOGÉN EREDETŰ ILLÉKONY SZERVES VEGYÜLETEK (BVOC) ÉS AZ ÓZON SZEREPE A NÖVÉNYFENOLÓGIÁBAN
}

\author{
Dávid Réka Ágnes, Barcza Zoltán \\ ELTE Meteorológiai Tanszék, 1117 Budapest, Pázmány Péter sétány 1/A. \\ e-mail: rekaagnesdavid@gmail.com,zoltan.barcza@ttk.elte.hu
}

\section{Bevezetés}

A növényfenológia a szárazföldi vegetáció éves ismétlődő fejlődési fázisaival foglalkozó interdiszciplináris tudományterület. A fenológia fontos szerepet tölt be az ökoszisztémában, befolyásolja a talaj-növény rendszer szénmérlegét, szabályozza a biogeokémiai és biofizikai visszacsatolásokat, illetve magát az éghajlati rendszert is (Richardson et al., 2013). A növényzet fenológiai ciklusa szorosan összefügg az időjárással, leginkább a hőmérsékleten és a csapadékmennyiségen keresztül (Piao et al., 2019; Zhang et al., 2019), de más környezeti változókkal is összefüggésbe hozható (fotoperiódus, téli hőmérséklet, tápanyag-ellátottság).

A növények életfolyamataik révén illékony szerves vegyületeket bocsátanak ki, ezeket együttesen BVOC-nak nevezzük (biogenic volatile organic compounds, magyarul biogén eredetü illékony szerves vegyületek). A BVOC-ok egyfajta szabályozó vegyületek, ezekkel kommunikálnak egymás között a növények, szabályozzák a gyümölcsérést és védekeznek a kártevők ellen. Emellett a BVOC-ok a légköri folyamatokban is részt vesznek, befolyásolják a csapadékképződést, a légkörben zajló kémiai folyamatokat, és szerepük van a szén globális körforgásában. A közepes szélességeken a növényzet életciklusa és a BVOC kibocsátás szorosan összefügg, ezért a BVOC kibocsátás a fenológiával együtt értelmezhető.

A globális éghajlatváltozás a növényzet aktív életciklusát is megbolygatja, aminek befolyása van az ökológiai folyamatokra, a mezőgazdaságra, erdészetre, emberi egészségre és a gazdaságra is. A változó fenológia hatással van a BVOC kibocsátásra, ami az éghajlati rendszerben lévő kölcsönhatások miatt vissza is hathat az időjárásra, és ezen keresztül a fenológiai ciklusra. Emiatt fontos, hogy a BVOC-ok eredetét, éghajlati rendszerben betöltött szerepét megértsük.

Tanulmányunkban áttekintjük a BVOC-ok forrását, szerepüket a Föld rendszerében, azon belül is a bioszférában és a légkörben. Összefoglaljuk a BVOC-ok gáz fázisának a kémiáját, részletezzük az oxidációját a légkörben, a BVOC kibocsátás összefüggését a szén-dioxid- és a troposzférikus ózon koncentrációjával. Majd néhány tanulmány és mérés eredményét ismertetjük, amelyek a földhasználatbeli változás következményeit vizsgálják. Kitérünk az éghajlatváltozás hatására és a várható kölcsönhatásokra, visszacsatolásokra.

Jelen munka abból a célból született meg, hogy legyen egy összefoglaló a BVOC vegyületekről, amelyek több tudományterületen is (levegőkémia és fizika, biológia, ökológia) jelentős szerepet töltenek be; ezt sematikusan az 1. ábra foglalja össze. Mivel a természetben sincsenek éles határok a tudományágak között, így a cél egy olyan anyag megírása volt, amely igyekszik minél alaposabban összeszedni az ismereteket, különös hangsúlyt fektetve a BVOC-ok szerepére a légkörben.

\section{Általánosan a BVOC-okról}

A BVOC a VOC-ok (volatile organic compounds, magyarul illékony szerves vegyületek) egy halmaza. Fontos megemlíteni, hogy az illékony szerves vegyületekbe a metán definíció szerint nem tartozik bele. A VOC-oknak átlagos légköri viszonyok között magas a telítési 
gőznyomásuk, nem kondenzálódnak. Ezen vegyületek légköri koncentrációja alacsonyabb a metánnál, habár a kibocsátás nagyjából kétszerese a metánénak, ennek oka, hogy sokkal reaktívabb.

$\mathrm{Az}$ illékony szerves vegyületeknek természetes és antropogén eredetű forrásai is vannak. Erdők, füves területek, óceánok és a talaj is bocsát ki VOC-okat, legnagyobb mennyiségben izopréneket. A legnagyobb emberi eredetü forrásai a kőolajfinomítás, a petrolkémia, a fafütés, a biomassza-, illetve hulladékégetés, a mezőgazdaság és a vegyipar. A teljes VOC kibocsátásnak 10-15\%-a antropogén eredetü, ami lokálisan lehet domináns. Telített és telítetlen szénhidrogének oxidációjával nyelődik el ${ }^{1}$.

A természetes eredetü, biogén illékony szerves vegyületeket a növényzet termeli. Szerepük van a növények növekedésében, fejlödésében, reprodukciójában és védelmében is. Ezen túl úgymond „,kommunikációs felületként” is müködnek a növényzet és a rovarok, illetve egymás között is. Mivel ezeknek a vegyületeknek nagy a reakcióképessége és nagy mennyiségben kerülnek a légkörbe, ezért nagy szerepet játszanak a légkör kémiai összetételének alakításában és fizikai karakterisztikáiban. Az antropogén eredetű változások perturbálják a kölcsönhatásokat és olyan változásokhoz vezethetnek, amelyek következményét nehéz megmondani a földi rendszerre vonatkozóan.

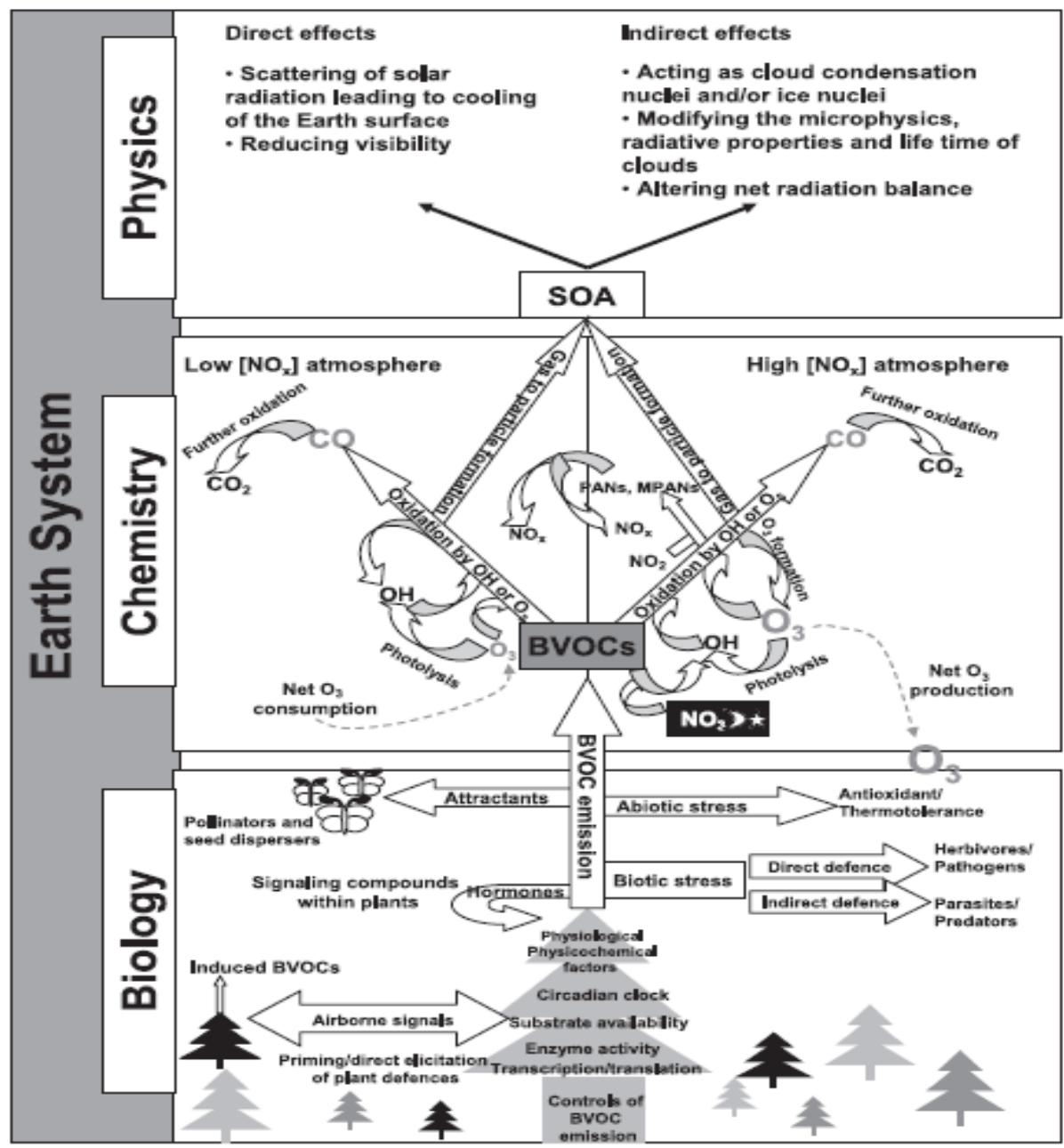

1. ábra: Sematikus ábra, amely összefoglalja a BVOC-ok jelenleg ismert szerepét a Föld rendszerében: biológiai, kémiai és fizikai szempontból. Forrás: Laothawornkitkul et al. (2009).

\footnotetext{
${ }^{1} \mathrm{http}: / /$ nimbus.elte.hu/oktatas/oktatasi_anyagok/levegokemia/11_Szen-vegyuletek.pdf
} 
Általánosságban elmondható, hogy a virágok és a gyümölcsök a legsokszínűbb BVOC termelök, az emissziós érték éréskor tetőzik. A legnagyobb mennyiségben viszont a levelek termelik a BVOC-okat. A biotikus és abiotikus stressz változást okozhat a BVOC-ok kibocsátásában. Az, hogy hogyan és miért szintetizálják a növények a BVOC-okat, és mik azoknak a hatása és funkciói, tudományos körökben igen kutatott téma. A levegőkémia a BVOC kibocsátás iránt azért érdeklődik, hogy a légkör összetételének változását és a levegökémia-éghajlat kapcsolatát vizsgálja.

A tudomány jelenlegi állása szerint a BVOC szintézist elsősorban a gének vezetik, viszont a résztvevő gének $\mathrm{kb}$. 90\%-a nem ismert. A BVOC kibocsátás erősen korrelál az enzim aktivitásokkal, továbbá függ a levélhőmérséklettől, a talajnedvességtől, a besugárzástól, a szén-dioxid, illetve ózon koncentrációjától is.

A BVOC-ok kétféle módon kerülnek a légkörbe, az egyik, amikor biokémiai úton szintetizálódnak. A három ilyen fó út: az izoprenoid, a lipoxigenáz és a sikimisav (nevét a japán csillagánizsról kapta) útjai. Ezen kívül növények is bocsátanak ki illékony vegyületeket, mint amilyen az etilén, a formaldehid, az aceton és az acetonaldehid. Utóbbi ismertebb út, az előző erősen kutatott téma (Laothawornkitkul et al., 2009).

\section{A BVOC-ok szerepe a Föld rendszerében a bioszférában}

A növények érzékelik a levegőben lévő vegyületek jelenlétét, amikre fiziológiai változással reagálnak.

A 20. században floridai farmerek kerozin égetésével érlelték a citrusféléket, ugyanis azt gondolták, hogy a hő segíti az érést. Ám az elektromos fütésre való áttérés után már nem jött meg a kívánt hatás. 1924-ben Frank E. Denny kimutatta, hogy a kerozin égetése során etilén keletkezik, amely mindenfajta gyümölcs érését elősegíti. Az etilén nemcsak a kerozin égetésénél van jelen, hanem pl. a tömjénfüstben is, amit a kínaiak körte érlelésére használtak. Az etilént nemcsak a kerozin és a tömjén füst tartalmazza, hanem minden gyümölcs is (1930ban mutatták ki). Az etilént a növény mint egy, ,illatot” érzékeli, és a gyors érés megindításának tekinti. Így lehet, hogy az egyiptomiak módszere is müködött, akik érett fügéket hasítottak fel, hogy a többi füge érését gyorsítsák (Chamovitz, 2017).

Az etilén szabadon diffundál a membránon keresztül, egy hatékony szabályozószer a növényekben (Laothawornkitkul et al., 2009). A célja a növény szempontjából valójában az, hogy szabályozza a reakciót a környezeti változásokra, mint pl. a szárazság vagy sérülés. Tulajdonképpen egy önerősítő folyamat, amely ökológiai szempontból azért fontos, mert elősegíti a magok terjedését, ugyanis az érett, illatozó gyümölcsöket megeszik az állatok, azok pedig így terjesztik a gyümölcsök magjait (Chamovitz, 2017). (2011-ig azt sikerült bizonyítani, hogy az etilént tényleg tudják azonosítani a növények.)

A BVOC-oknak a reprodukcióban is van szerepük, oly módon, hogy a virágzást segítik, illatanyagokkal vonzzák a beporzókat, akik az illatok alapján (eltérő BVOC arány) meg tudják különböztetni a fajokat. Farré-Armengol et al. (2015) öt mediterrán fajt vizsgált, abból a szempontból, hogy a beporzókat a szaglószervei által csalogatják-e az általuk kibocsátott BVOC-okkal vagy inkább a „díj” vonzza őket, azaz a nektár és a pollen. A BVOC-oknak olyan szerepe is van, hogy az illatok, föleg a terpenoidok (és színek) alapján a beporzók felismerik a virágokat, tehát a fajt, így „biztosítják a minőséget”. A vizsgált fajokról az derült ki, hogy a virágzás alatt nem nőtt meg szignifikánsan a kibocsátott izoprén és oxidált VOC-ok mennyisége. A terpén kibocsátást a környezeti tényezők befolyásolják, leginkább a hőmérséklet és a nedvesség. A 2. ábra az egyik vizsgált virág, a Biscutela laevigata eredményeit mutatja, a vizsgált év 2011 volt. 


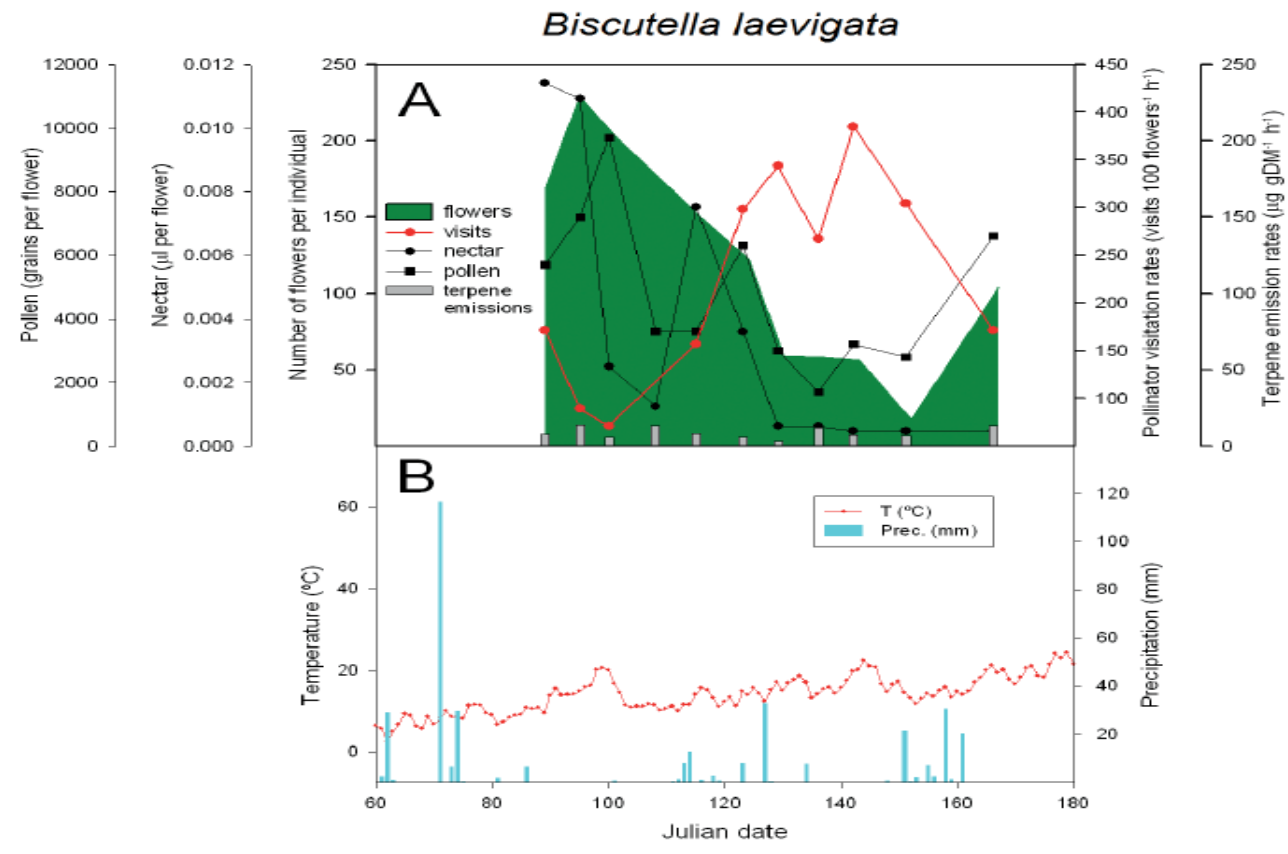

2. ábra: (A) A virágok száma, a nektár és a pollen termelés, terpén kibocsátás és a beporzók látogatása. Az értékek hetente öt mintavételt jelentenek.

(B) Hőmérséklet $\left({ }^{\circ} \mathrm{C}\right)$ és a csapadékösszeg $(\mathrm{mm})$ a vizsgált időszak alatt. Forrás: Farré-Armengol et al. (2015).

A BVOC-ok további szerepe a bioszférában, hogy védelmet nyújtanak a biotikus stressz ellen, ugyanis néhány illat vonzza, néhány pedig taszítja a rovarokat, tehát a beporzás a reprodukciót segíti, a taszítás pedig a károkozók elleni védelemért szolgál. Néhány BVOC, mint a metil-szalicilát, a metil-jazmonát vagy a terpének a növények közötti kommunikációban vállalnak szerepet a levegő útján terjedve, illetve sejtek között növényeken belül. Ez úgy jöhet létre, hogy ha megsérül a növény, akkor illatanyag szabadul fel, amit érzékel ugyanaz az egyed vagy akár egy másik. Ez olyan kérdéseket vet fel, hogy a növények tudnak-e különbséget tenni a mechanikai kárt okozó biotikus (károkozó) és az abiotikus (pl. erős szél, jégeső) faktorok között, és ha igen, akkor hogyan? Ezt a fajta kommunikációt megértve javítható lenne a fenntartható mezőgazdaság hatékonysága (Laothawornkitkul et al., 2009).

A baktériumok ellen a növény (a korábban már szóba került) metil-szalicilátot (MeSA) (a szalicilsav illékony formája), a rovarok ellen pedig metil-jazmonátot (MeJA) termel. A metilszalicilát nagyon hasonlít a szalicilsavhoz, amiből az Aspirin készült (acetilszalicilsav elővegyülete), lázcsillapító és fájdalomcsillapító hatása van. A veszély „megérzése” után az egészséges részek reagálnak, pl. elhalt sejtekből gátak jönnek létre (Chamovitz, 2017).

A fotoszintézist az izoprének és a monoterpének olyan károktól védik, amelyeket az átmeneti magas hőmérsékletü időszakok okoznak, amely a fotoszintézis visszaeséséhez vezethet. Magas hőmérsékleten a membránon lyukak keletkeznek és szivárognak, akkor ezt a szivárgást szünteti meg az izoprén, olyan módon, hogy fokozza a hidrofób kölcsönhatást. Ismert tény, hogy az ózon oxidatív hatása ellen is védelmet nyújt, mint antioxidáns (Laothawornkitkul et al., 2009).

\section{A BVOC-ok szerepe a Föld rendszerében a légkörben}

A BVOC fluxust a bioszféra felöl a légkör felé nagyon nehéz megbecsülni, jelenlegi becslés szerint ez kb. $700-1000 \times 10^{12}$ g C/év (Laothawornkitkul et al., 2009). A BVOC fluxus messze 
meghaladja az antropogén eredetű VOC fluxust (Crutzen et al., 2008). Az izoprének, és a monoterpének jelentik a legnagyobb mennyiséget a BVOC-ok között. Továbbá kiemelkedő a metanol, az aceton és az acetaldehid koncentrációja. A C15-ös szeszkviterpénekről is gyakran szó esik a növényfenológiában, amikor a BVOC-ok szerepéről beszélünk, ám koncentrációjuk becslése nehéz, mivel alacsony a gőznyomásuk és nagy a reaktivitásuk. Ök egyébként fontos prekurzorai a másodlagos természetes aeroszoloknak ( $\mathrm{SOA}=$ secondary organic aerosol).

\section{A BVOC-ok oxidációja a légkörben}

A BVOC-ok oxidálódnak a légkörben, végső soron szén-dioxiddá és vízzé alakulnak. Oxidálószer lehet az ózon és az $\mathrm{OH}$ is. Nedves ülepedéssel kerül ki a légkörből számos olyan részben oxidált köztes termék, amelyek vízben oldódnak. Elsősorban az $\mathrm{OH}$ gyökök reagálnak a VOC-okkal, a reakcióban részt vevő $\mathrm{OH}$ jöhet a troposzférikus ózon fotolíziséből vagy oxigén atom vízgőzzel való reakciójából, illetve jöhet peroxi gyökökből $\left(\mathrm{RO}_{2}, \mathrm{R}\right.$ bármilyen szerves vegyület). Éjszaka, amikor az $\mathrm{OH}$ koncentráció gyakorlatilag 0 , akkor a BVOC oxidációját az $\mathrm{NO}_{3}$ nitrát gyök veszi át. Mivel az $\mathrm{NO}_{3}$ napközben a fény segítségével reagál, ezért csak éjszaka nő meg a koncentrációjának a mennyisége. Bár a BVOC-ok oxidációs reakciói nem teljesen ismertek részleteibe menően, viszont egyértelmü, hogy a BVOC oxidációja befolyásolja a troposzféra oxidációs képességét is, illetve más gázok keletkezésének sebességét és mennyiségét is (Laothawornkitkul et al., 2009).

\section{A BVOC-ok gáz fázisának kémiája}

A troposzférikus ózonkoncentráció növekedését eredményezi a BVOC-ok $\mathrm{OH}$-val való reagálása $\mathrm{NO}_{\mathrm{x}}$ jelenlétével:

$$
\begin{gathered}
\mathrm{NO}+\mathrm{O}_{3} \rightarrow \mathrm{NO}_{2}+\mathrm{O}_{2} \\
\mathrm{NO}_{2}+\mathrm{hv}(<245 \mathrm{~nm}) \rightarrow \mathrm{NO}+\mathrm{O} \\
\mathrm{O}+\mathrm{O}_{2}+\mathrm{M} \rightarrow \mathrm{O}_{3}+\mathrm{M} \\
\mathrm{NO}+\mathrm{HO}_{2} \rightarrow \mathrm{NO}_{2}+\mathrm{OH} / \mathrm{NO}+\mathrm{RO}_{2} \rightarrow \mathrm{NO}_{2}+\mathrm{RO}
\end{gathered}
$$

Tehát a BVOC kibocsátás regionális skálán fontos szempont a fotokémiai szmog kialakulásánál. Továbbá, mivel $\mathrm{OH}$ az elsődleges oxidálója a metánnak, a vízgőz és a széndioxid után a harmadik legfontosabb üvegházgáznak, a BVOC kibocsátás megemelheti a metán tartózkodási idejét a légkörben, ezzel befolyásolva a Föld sugárzási háztartását. A hőmérsékletváltozás pedig visszahat a BVOC kibocsátásra.

Hasonlóan müködik szén-monoxiddal is:

$$
\begin{gathered}
\mathrm{CO}+\mathrm{OH} \rightarrow \mathrm{CO}_{2}+\mathrm{H} \\
\mathrm{H}+\mathrm{O}_{2}+\mathrm{M} \rightarrow \mathrm{HO}_{2}+\mathrm{M} \\
\mathrm{NO}+\mathrm{HO}_{2} \rightarrow \mathrm{NO}_{2}+\mathrm{OH}
\end{gathered}
$$

A CO ózon nyelőként vagy forrásként is funkcionál $\mathrm{NO}_{\mathrm{x}}$ jelenlététől függően.

A VOC-ok légköri oxidációja $\mathrm{NO}_{\mathrm{x}}$ jelenlétében természetes nitráttá alakulhat, mint amilyen a PAN (peroxiacetil nitrát) vegyületek. A PAN-oknak nagyobb a légköri tartózkodási ideje, mint a $\mathrm{NO}_{\mathrm{x}}$-oknak, így nagyobb skálán is el tudnak keveredni. Mivel melegebb levegöben bomlik és $\mathrm{NO}_{\mathrm{x}}$ vegyületet hoz létre, így az $\mathrm{NO}_{\mathrm{x}}$ koncentráció egyes területeken anélkül nő, hogy lokális forrása lenne. Ez végső soron ózonképződéshez vezet ${ }^{1}$.

\section{A BVOC-ok befolyása az aeroszol képzödésre}

A BVOC-ok a levegőkémiában nemcsak a gázfázisra vannak hatással, hanem az aeroszolok képződésre is. A POA (primary organic aerosols) a fosszilis üzemanyagok és a biomassza égetésből származik. A másodlahos aeroszolok, a SOA (secondary organic aerosols) kémiai 
úton keletkik a légkörben. A POA kibocsátás csökken a félig illekony (semivolatile) vegyületek légköri koncentrációjának növekedésével, mert tulajdonképpen hígul (Fierravanti, 2017).

Az, hogy tiszta levegőben a BVOC-ok oxidációja hogyan vezet SOA-hoz még kevéssé ismert, az viszont bizonyos, hogy a BVOC oxidációja során a termékeknek általában alacsonyabb a páranyomásuk, mint az elsődleges vegyületeknek, így könnyebben kondenzálódhatnak. Kísérletek és megfigyelések szerint a vegetáció által kibocsátott terpének és a szeszkviterpének többségében szignifikáns forrása lehet a SOA-nak (A közelmúltban történt trópusi esőerdők megfigyelése során mégsem volt meg a várt mértékben a SOA.).

Az aeroszolok közvetlenül befolyásolják a klímát a napsugárzás szórásával, közvetett módon pedig nukleációs magként a felhőképződés során (Laothawornkitkul et al., 2009; Fierravanti, 2017).

\section{A BVOC-ok változó globális környezetben}

Fentebb arról volt szó, hogy a BVOC-oknak milyen szerepe van a földi környezetben, a következőkben pedig arról fog szólni az értekezés, hogy a környezeti változások hogyan befolyásolják a BVOC termelést.

Mivel a bioszféra és a légkör is változik, továbbá az antropogén hatások megmutatkoznak, a BVOC kibocsátás is még inkább változni fog, amely különböző kölcsönhatásokat eredményez. Ha megérhető a jövőbeli környezeti változások következtében történő változás a BVOC emisszióban, akkor egyszerübb lehet előre jelezni a változások nagyságrendjét és annak hatásait.

\section{A légköri szén-dioxid koncentráció és BVOC kibocsátás}

Különböző kutatások szerint a növekvő $\mathrm{CO}_{2}$ koncentráció különböző hatással volt a BVOC emisszióra, ez azt jelenti, hogy más-más kutatások szerint növekedett, csökkent vagy nem mutatható ki szignifikáns változás (Laothawornkitkul et al., 2009).

Egy bizonyos szintig a növényzet $\mathrm{CO}_{2}$ felvétele növekszik, de a BVOC kibocsátás is, amely szintén hatással van az éghajlatra. A BVOC-ok légköri tartózkodási ideje rövid, de fontos szerepük van az aeroszolok létrejöttében. Az aeroszolok felhőképződés kapcsán hütő hatással rendelkeznek. Továbbá az aeroszolok szórják a napsugárzást, ezzel az elosztással a növényzet jobban hozzáfér, így a fotoszintézissel még több $\mathrm{CO}_{2}$-ot tud megkötni. A BVOCok az ózonképződést is növelik, iletve a metán tartózkodási idejét, így hozzájárul az üvegházhatáshoz. Az, hogy a BVOC-ok végső soron csökkentik vagy növelik a hőmérsékletet a negatív (növekvő albedó és $\mathrm{CO}_{2}$ megkötés) és a pozitív (növekvő üvegház-hatás) visszacsatolások súlyától függ (Penuelas et al., 2009).

\section{A troposzférikus ózon koncentráció és BVOC kibocsátás}

Több, mint valószínű, hogy a felszíni $\mathrm{O}_{3}$ koncentráció változni fog a jövőben. Az ózon már napjainkban is kiemelt regionális légszennyező anyag. Az, hogy az $\mathrm{O}_{3}$ koncentráció változása hogyan befolyásolja a BVOC termelést (csökken, nő vagy nem változik) fajspecifikus és évszakfüggő (Laothawornkitkul et al., 2009).

A városok arculatában fontos szerepe van az erdősített részeknek. Paradox módon a fák rontanak a levegőminőségen a BVOC kibocsátás által, amely vegyületek a $\mathrm{NO}_{\mathrm{x}}-\mathrm{kal}$ troposzférikus ózon, fotokémiai szmog kialakulásához vezet. (lásd: $A$ BVOC-ok gáz fázisának kémiája c. alfejezet). Természetesen a városi faültetésnek számos pozitív hatása van: a városi 
hősziget effektus csökkentése, a vízmegkötéssel befolyásolja a vízelvezetést, továbbá valamennyi $\mathrm{CO}_{2}$ megkötés is történik.

Amikor magas a $\mathrm{NO}_{\mathrm{x}}$ koncentráció, akkor egyetlen izoprén molekula több $\mathrm{O}_{3}$ molekulát képes létrehozni. Városi környezetben az $\mathrm{OH}$ reakcióképessége függ a hőmérséklettől, a $\mathrm{NO}_{\mathrm{x}}$ koncentráció szint pedig a városi légszennyezettségtől. A fák BVOC kibocsátása fajspecifikus és a meteorológiai állapothatározóktól függ (pl. szárazság alatt csökken a monoterpén kibocsátás).

A jövőben még több faültetéssel kell számolni, különösen a fejlődő országokban, így a levegőminőség romlása a nagyvárosokban még nagyobb területeket fog érinteni, ami a városlakók egészségi állapotát befolyásolja, ez pedig az egészségügynek még több kiadást jelent. A levegőkémia dinamikájának jobb megértésével megelőzhető lenne ez a probléma (Fierravanti, 2017).

A magas ózonkoncentráció a növényekben lévő klorofillt csökkenti, így visszaesik a fotoszintézis, ez pedig a $\mathrm{CO}_{2}$ felvétel csökkenéséhez vezet, ami pedig tovább erősíti a felmelegedést. A troposzférikus ózon a gabonák termelésében akár 30\% visszaesést is okozhat (Anav et al., 2018).

$\mathrm{Az}$ erdők ózonfelvétele több meteorológiai állapothatározóval és speciális függvénnyel becsülhető a fenológiai ciklus kezdetén. Ez a függvény a legtöbb esetben szélesség és topográfia alapú modellen alapszik. Anav et al. (2018) két műholdas adatsort használt fel, hogy 2011-re hatféle módszert vizsgáljon Európára, amelyek nagy különbségeket eredményeztek. Érdekes módon az összes módszer hasonló térbeli mintázatot mutat az erdők ózonfelvételéről, azonban nagyságában különbség van köztük, ami 25\%-ot is elérhet. A cikk eredményei azt mutatják, hogy az ózon fluxus több figyelmet érdemel a fenológiai modellekben.

\section{Változás a földhasználatban (tanulmányok, mérések eredményei)}

A Föld felszínén bekövetkező változások nemcsak a klímaváltozás következményei, hanem az ember hatása is az urbanizáció, a mezőgazdaság és az iparosodás által. Mivel az elsődleges BVOC kibocsátók nem a füfélék és a gabonák, hanem az erdők, az erdőirtás következtében csökken a BVOC kibocsátás (Laothawornkitkul et al., 2009).

A BVOC összetétel és kibocsátás környezet- és növényspecifikus, az erdőket szélesebb körben tanulmányozták már, mint a termőföldeket (Bachy et al., 2016).

A bioüzemanyag egyre elterjedtebb a világon, különösen Európában, ami nagyobb mennyiségü kibocsátott BVOC koncentrációhoz vezet, ez pedig a levegőminőséget befolyásolja.

Jelenleg a világ nagy részén, különös tekintettel a trópusokra, a legnagyobb földhasználat változásban fellépő tényező az energianövények termesztése. Európában törekvések vannak arra, hogy a biomasszát, mint megújuló energiaforrást hasznosítsák. Eltekintve a közvetlen biomassza égetéstől, a biogáz erjesztése a legfontosabb út ezen a vonalon, jelenleg leginkább alapanyagként a kukoricát részesítik előnyben (Wi $\beta$ et al., 2017).

Wiß et al. (2017) cikke a BVOC kibocsátás megváltozásokat vizsgálta északkeletnémetországi kukoricaföld fölött a környezeti tényezők, a fenológiai ciklusok és a növény állapotának függvényében.

A kutatás során az derült ki, hogy a kukoricatáblák BVOC kibocsátását nagy mértékben a hőmérséklet és a sugárzás határozza meg. Az évszakos változás a monoterpén és a szeszkviterpén kibocsátásban, a szubsztrátok elérhetősége a bioszintézishez, a fehérjeszint és az enzimaktivitás is érintve van. Míg a molekuláris biokémiát érinti az időjárás, addig a nagy terpén kibocsátás virágzás idején és más BVOC-ok érzékenysége nagy sugárzás esetén a gyümölcsérés fázisában nem magyarázható az évszakos fejlődéssel. A terpén kibocsátás 
különösen virágzás idején történik, míg a nem terpén vegyületeket nem tudták összefüggésbe hozni a fenológiai ciklussal, viszont a pillanatnyi időjárási helyzettel magyarázható.

Kukorica vonatkozásában (ami globálisan a második, C4-sek közül pedig a legfontosabb gabona a világon) az első átfogó tanulmány Bachy et al. (2016) munkája volt. Mivel ilyen mérésekből hiány van, nagy a bizonytalánság a kukorica BVOC kibocsátás becslésekben. Bachy et al. (2016) tanulmánya ökoszisztéma szinten méri eddy kovariancia módszerrel a BVOC fluxust Belgiumban. A mérés 2012-ben történt, a mütrágyázás időszakát kivették belőle. Egészen pontosan diszjunkt eddy kovariancia tömeg szkenelési technikát alkalmaztak (disjunct eddy covariance by mass scanning (DEC-MS) technique). Ez a módszer a vertikális szélkomponens és a BVOC keverési arányának a kovarianciáját származtatja (Bachy et al., 2016).

Az eddy kovariancia (EC) módszerhez a vertikális szélsebesség fluktuációját és a nyomgázok koncentrációját szükséges megmérni nagy időbeli felbontással. Hagyományosan ezt anemométerek és gáz mérőmüszerekkel teszik meg, amelyek gyors válaszidőre és magas adatmintavételi frekvenciára képesek annak érdekében, hogy a nagy és alacsony frekvenciát is tartalmazzák, azaz hogy elég hosszú legyen az átlagolási időszak. Ez általában 0,1 s szokott lenni, viszont ilyen rövid válaszidővel nem érhető el könnyen folytonos idősor. Egy lehetséges módja annak, hogy a követelményt csökkenteni lehessen, az a diszjunkt eddy kovariancia módszer (DEC) alkalmazása. Ennél a módszernél a teljes folytonos koncentrációnak és a szél adatsornak csak egy részhalmaza van használva a fluxus meghatározására. Így a csökkentett mintaelem szám nem folytonos mintavételt tesz lehetővé, amely lehetőséget ad a lassabb nyomgázok megfigyelésére vagy több vegyület mérésére ugyanazzal a müszerrel. Tehát, amikor az eddy kovariancia mérésnél $\Delta$ mintavételezési idő jóval hosszabb, mint a rendszer válaszideje, akkor DEC-ről beszélünk. Sima EC mérésnél $\Delta=0,1 \mathrm{~s}(10 \mathrm{~Hz})$, ez fél órára 18000 mért értéket jelent. DEC-nél $\Delta=1-30 \mathrm{~s}$, ami fél órára 70 1800 mintát jelent. A módszer modellszimulációkkal és kísérletekkel is validálva lett. Nincsen benne szisztematikus hiba, de az alacsonyabb mintaelem szám növeli a random bizonytalanságot a mért fluxusokban.

DEC-MS esetén $\Delta=1-10 \mathrm{~s}$, ez a módszer alkalmas folytonos minták vételezésére, amely többféle gázra is alkalmazható, viszont csak a különböző tömegek egymás utáni észlelése lehetséges, így minden egyes vegyület diszkrét idősorként van mérve (Rinne \& Ammann, 2012).

Bachy et al. (2016) a kukorica növekedési időszakát a BBCH skála alapján (Biologische Bundesanstalt, Bundessortenamt and CHemical industry) öt fenofázisra különítették el: (G) csírázás, (L) levélbomlás, (S) szárhosszabbodás és levélfelület fejlődése, (R1) virágzat kialakulása, virágzás és gabona megjelenése (R2) gabonaérés.

A mérés során leginkább metanolt és ecetsavat mértek ki, utóbbi leginkább a növekedési időszakban volt jelen. Ezek a kicserélődések kétirányúak voltak. Mértek még acetaldehidet, acetont és más oxidált VOC-okat is, ahol a terpének, a benzol és a toluol kicserélődések bár kicsik voltak, de jelentősek. Meglepő módon a BVOC kicserélődések a csupasz talaj és a fejlett növényzet esetén is ugyanolyan nagyságúak voltak, ami arra mutat, hogy a talaj a mezőgazdaság egyik fö BVOC tározója. Számszerüsítve, a mért BVOC kibocsátás alacsonyabb volt, mint amit a jelenlegi modellek használnak $\mathrm{C} 4$-es növényekre, különösen terpénekre. Nagy az eltérés a BVOC kibocsátásokban, a SEF-et (standard emission factor) regionálisan eltérőnek kéne venni.

A talaj fontos szerepet játszik az ökoszisztéma BVOC kicserélődési folyamataiban, amit figyelembe kéne venni a modellekben is. Továbbá jobban meg kéne ismerni a mezőgazdasági talajok és a légkör közöttti kicserélődéseket annak érdekében, hogy a kicserélődési folyamatok miért csökkennek a kukorica növekedési időszakában. Ahhoz, hogy a jövőbeli éghajlatot modellezni lehessen, szükséges az éghajlati komponensek és azok 
kölcsönhatásainak megértése. Az egyik ilyen komponens a VOC vegyületek. A cikk arra figyelmezteti a modellezőket, hogy különböző régiókon nagy eltérések vannak a kukoricatáblák BVOC kibocsátásában, nem extrapolálhatók a régiók, egyik nem reprezentatív a másikra nézve. Szükséges a BVOC-ok (különösen az oxidált VOC-ok) és a növényzet és a légkör közötti kicserélődési folyamatok jobb megismerése, annak érdekében, hogy fény derüljön a nagy BVOC koncentráció különbségek okára és hogy hogyan viselkednek sztenderd kondíciók mellett a modellekben, hogy fel lehessen skálázni (Bachy et al., 2016).

A korábbiakban a bioüzemanyagról és a kukorica, repce vagy energiafú iránti kereslet növekedéséről volt szó és ennek kapcsán a BVOC kibocsátásról. Ám szót érdemel, hogy ezen növények alkalmazása, mint megújuló energiaforrás környezetvédelmi szempontból nem biztos, hogy tényleg elönyös, ugyanis a felszín alatti szennyeződéseket, további üvegházgázok kibocsátást és a biodiverzitás csökkenését okozza (Wiß et al., 2017).

A Nobel-díjas Crutzen 2008-as cikkében ír a bioüzemanyagokról (mint amilyen a biodízel a repcéből vagy a bioetanol a búzából). Ha a bioüzemanyagok termesztéséhez köthető extra $\mathrm{N}_{2} \mathrm{O}$ kibocsátásának $\mathrm{CO}_{2}$ ekvivalens értékét nézzük, és ezt összehasonlítva a fosszilis tüzelőanyagokból származó $\mathrm{CO}_{2}$ kibocsátás „megtakarításával”, amit a bioüzemanyagok hasznlatából nyerünk, akkor a bioüzemanyag termelése során, attól függően, hogy a növényzet a mütrágyákból milyen hatékonysággal veszik fel a nitrogént, a $\mathrm{N}_{2} \mathrm{O}$ kibocsátás által a felmelegedés hasonló vagy még nagyobb mértékü lesz, mint a ezáltal a $\mathrm{CO}_{2}$ kibocsátás csökkenésének a hütő hatása.

A $\mathrm{N}_{2} \mathrm{O}$ átlagos légköri tartózkodási ideje kb. 100-150 év, átlagos melegedési potenciálja (GWP) 296-szor nagyobb, mint a $\mathrm{CO}_{2}$-nak. A GWP-t a gázok üvegházhatásának számszerüsítésére használják. Azonos tömegü szén-dioxidhoz képest határozzák meg az értékét, meghatározott időintervallumra (ez általában 100 év). A nitrogéntartalmú mütrágyázás - ami az energianövények termesztéséhez különösen fontos $-\mathrm{a} \mathrm{N}_{2} \mathrm{O}$ kibocsátás növekedését eredményezi (Crutzen et al., 2008).

\section{Globális felmelegedés és a BVOC kibocsátás, kölcsönhatások és visszacsatolások}

A hőmérséklet emelkedése közvetlenül fogja érinteni a növényzet aktív növekedési időszakát. A BVOC kibocsátás erősen hőmérsékletfüggő, mivel magasabb hőmérsékletek kémiai reakciókat indukálnak, ugyanis növeli a sejtek közötti diffúziót és az illékony vegyületek gőznyomását. A globális hőmérséklet $2-3{ }^{\circ} \mathrm{C}$-kal való emelkedése $25-45 \%$-os BVOC emisszió növekedést eredményezne.

A felmelegedés közvetetten is befolyásolhatja a BVOC termelést, ugyanis megváltozhatnak a fajok jellemzői. A várható melegedéssel nagyobb lesz a BVOC kibocsátás. $\mathrm{Az}$ erős hőmérséklet-függés miatt, a megnövekedett BVOC mennyiség csökkenti az $\mathrm{OH}$ koncentrációt, ami a troposzférikus metán és $\mathrm{CO}$ nyelője, így további melegedés várható (Laothawornkitkul et al., 2009).

A tavaszi levélbontás után csökkenő albedó tovább melegíti a felszínt, amely különösen azokra a területekre nézve veszélyes, amelyek nagy albedóval rendelkeznek (pl. a hóval borított területek), ezek pedig térbeli skálán akár száz-ezer kilométerre is lehetnek (Penuelas et al., 2009).

A növekvő izoprén kibocsátásnak is kettős hatása lehet a magasabb hőmérsékletekre: $\mathrm{NO}_{\mathrm{x}^{-}}$ szel szennyezett levegőben $\mathrm{O}_{3}$ keletkezést von maga után, míg a megnövekedett $\mathrm{O}_{3}$ koncentráció növénykárosodáshoz vezet, így csökken az izoprén kibocsátás.

Az éghajlatváltozás kapcsán a szárazság egyre gyakoribbá válik bizonyos területeken, amely a folyamatok nem megfelelő müködéséhez vezet, és emiatt a BVOC-ok kibocsátására is stressz hatásként mutatkozik meg (Penuelas et al., 2009). A csapadék mennyiségében és területi eloszlásában is változás várható az IPCC modellfuttatásai alapján. Súlyos, tartós 
vízhiány hervadáshoz, illetve idő előtti szárazodáshoz, és a fotoszintézis visszaeséséhez vezet (Laothawornkitkul et al., 2009). Valójában a korábbra tolódó és elhúzódó vegetációs időszak fokozott evapotranszspirációt okozhat, amely fokozza a hőhullámokat Európában és a talajnedvesség csökkenésével jár együtt. A talaj nedvességtartalmának kimerítése csökkenti a párolgás általi hütést, ezáltal növekszik a felszíni hőmérséklet és valószínüsíthetően csökken a nyári csapadékmennyiség.

Korábbi fejezetekben a BVOC-ok, mint a növényzet direkt és indirekt védekező mechanizmusai bemutatásra kerültek. Környezeti változás eredményeképpen az emissziójuk megváltozása során ezek a mechanizmusok is megváltozhatnak vagy semmissé válhatnak. A $\mathrm{CO}_{2}$ koncentráció növekedés megzavarhatja a BVOC termelést, így gyengítve a növények védekezését a növényevők és a paraziták ellen.

Az egyszerüsített modellek megfontolt kidolgozást igényelnek, hiszen a legtöbb BVOC a növényzet biotikus és abiotikus stressz elleni védelemét szolgálja. Valószínúsíthető, hogy a BVOC-oknak más szerepe is van a növényekben, így a megváltozott BVOC kibocsátás más stresszekre is máshogy reagál, amely további változást okozhat globálisan. Ilyen pl. a csapadék mennyiségének és területi eloszlásának változása, a biomassza, növényfajok földrajzi újraeloszlása, az aktív növekedési időszak hosszának megváltozása vagy a kórokozók inváziója (Ghimire et al., 2017; Laothawornkitkul et al., 2009).

A jelenlegi modellek nem megfelelően reprezentálják ezeket a kölcsönhatásokat, visszacsatolásokat, részben azért, mert a globális felmelegedés kombinált hatásai más környezeti hatásokkal együtt a BVOC kibocsátásra nem mindig egyértelmü (Laothawornkitkul et al., 2009). Az, hogy a hosszabb aktív fenológiai időszak gyengíteni vagy erősíteni fogja-e a globális melegedést a vízellátottságtól és a regionális karakterisztikáktól függ (Penuelas et al., 2009).

\section{Összefoglalás}

Ez a tanulmány azért jött létre, hogy egy összefoglalást nyújtson a biogén eredetủ illékony szerves vegyületekről, és valamennyire lehetővé tegye az átjárást a különböző tudományterületek között, hiszen a BVOC-oknak a légkörben legalább annyira jelentős szerepe van, mint a bioszférában. A bioszféra és a légkör közötti kapcsolat fontos a fenológiai ciklusban, ezen rendszerek és a közöttük lévő kölcsönhatások ismerete egyre inkább szükségszerü, különös tekintettel az éghajlatváltozásra. Pontosabb megismerése lehetővé teszi a fenológia modellezésének pontosítását, ami pedig a légköri szénciklusban beálló változások nyomon követését teszi lehetővé, így pontosabb előrejelzést lehet készíteni, mind hosszabb skálán az éghajlatra, mind rövidebb időtávra, az időjárás vonatkozásában.

A BVOC-ok szoros kapcsolatban állnak a troposzférikus ózon képződésével, így szerepet játszanak a városi levegőminőség alakításában is. Mivel ezeket a vegyületeket a növényzet bocsátja ki, így még inkább igény van a részletesebb megismerésükre, ugyanis az egyre inkább növekvő élelmiszerigény miatt a mezőgazdaság kapcsán egyre nagyobb változás áll be a földhasználatban. Nemcsak a mezőgazdaság, hanem az energiaipar is hatással van a légköri BVOC koncentrációra, hiszen sokan a fosszilis üzemanyagok alternatívájaként tekintenek a bioüzemanyagra, aminek az alapját szolgáló növények termesztése során központi téma a BVOC kibocsátás.

\section{Hivatkozások}

Anav, A., Liu, Q., Marco, A.D., Proietti, C., Savi, F., Paoletti, E., Piao, S., 2018: The role of plant phenology in stomatal ozone flux modeling. Global Chang Biology, 14. https://doi.org/10.1111/gcb.13823 
Bachy, A., Aubinet, M., Schoon, N., Amelynck, C., Bodson, B., Moureaux, C., Heinesch, B., 2016: Are BVOC exchanges in agricultural ecosystems overestimated? Insights from fluxes measured in a maize field over a whole growing season. Atmospheric Chemistry and Physics, 16: 5343-5356. https://doi.org/10.5194/acp-16-5343-2016

Chamovitz, D., 2017: What a plant knows. A Field Guide to the Senses. Park kiadó, ISBN 978-963-355-460-9

Crutzen, P.J., Mosier, A.R., Smith, K.A., Winiwarter, W., 2008: $\mathrm{N}_{2} \mathrm{O}$ release from agro-biofuel production negates global warming reduction by replacing fossil fuels. Atmospheric Chemistry and Physics, 8: 389-395. https://doi.org/10.5194/acp-8-389-2008

Farré-Armengol, G., Filella, I., Llusia, J., Penuelas, J., 2015: Relationships among floral VOC emissions, floral rewards and visits of pollinators in five plant species of a Mediterranean shrubland 10. Plant Ecology and Evolution, 148(1): 90-99. https://doi.org/10.5091/plecevo.2015.963

Fierravanti, A., 2017: Eligible reference cities in relation to BVOC-derived O3 pollution 8. Urban Forestry \& Urban Greening, 28: 73-80. https://doi.org/10.1016/j.ufug.2017.09.012

Ghimire, R.P., Kivimäenpää, M., Kasurinen, A., Häikiö, E., Holopainen, T., Holopainen, J.K., 2017: Herbivore-induced BVOC emissions of Scots pine under warming, elevated ozone and increased nitrogen availability in an open-field exposure. Agricultural and Forest Meteorology, 242: 21-32. https://doi.org/10.1016/j.agrformet.2017.04.008

Laothawornkitkul, J., Taylor, J.E., Paul, N.D., Hewitt, C.N., 2009: Biogenic volatile organic compounds in the Earth system: Tansley review. New Phytologist, 183: 27-51. https://doi.org/10.1111/j.1469-8137.2009.02859.x

Penuelas, J., Rutishauser, T., Filella, I., 2009. Phenology Feedbacks on Climate Change. Science, 324: 887-888. https://doi.org/10.1126/science.1173004

Piao, S., Liu, Q., Chen, A., Janssens, I.A., Fu, Y., Dai, J., Liu, L., Lian, X., Shen, M., Zhu, X., 2019: Plant phenology and global climate change: Current progresses and challenges. Global Change Biology, 14619. https://doi.org/10.1111/gcb.14619

Richardson, A.D., Keenan, T.F., Migliavacca, M., Ryu, Y., Sonnentag, O., Toomey, M., 2013: Climate change, phenology, and phenological control of vegetation feedbacks to the climate system. Agricultural and Forest Meteorology, 169: 156-173. https://doi.org/10.1016/j.agrformet.2012.09.012

Rinne, J., Ammann, C., 2012: Disjunct Eddy Covariance Method. In: Aubinet M., Vesala T., Papale D. (eds) Eddy Covariance. Springer Atmospheric Sciences. Springer, Dordrecht. pp. 291-307. https://doi.org/10.1007/978-94-007-2351-1_10

Wiß, F., Ghirardo, A., Schnitzler, J-P., Nendel, C., Augustin, J., Hoffman, M., Grote, R., 2017: Net ecosystem fluxes and composition of biogenic volatile organic compounds over a maize field-interaction of meteorology and phenological stages, Global Change Biology Bioenergy, 183: 27-51. https://doi.org/10.1111/gcbb.12454

Zhang, L., Lei, H., Shen, H., Cong, Z., Yang, D., Liu, T., 2019. Evaluating the Representation of Vegetation Phenology in the Community Land Model 4.5 in a Temperate Grassland. Journal of Geophysical Research: Biogeosciences, Journal of Geophysical Research: Biogeosciences, 124, 187-210. https://doi.org/10.1029/2018JG004866

\section{ORCID}

Barcza Z. (D) https://orcid.org/0000-0002-1278-0636 